\title{
Analysis of Feeder Needs to Support the Implementation of LRT in Palembang
}

\author{
Joni Arliansyah ${ }^{1,2^{*}}$ \\ ${ }^{1}$ Department of Civil Engineering, Faculty of Engineering, University of Sriwijaya, Indonesia \\ ${ }^{2}$ National Center for Sustainable Transportation Technology, Indonesia \\ *Email: joniarliansyah@yahoo.com
}

\begin{abstract}
Palembang City in August 2018 was the first city in Indonesia which operated a mass transit of Light Rail Transit (LRT). LRT in Palembang City has a length of $23 \mathrm{~km}$ and 13 stations that stretch from the Airport station to the DJKA station. In its first year of operation, it was noted that the number of passengers using LRT was still very small, some efforts were needed to increase the number of LRT passengers. This study aimed to increase the number of LRT passengers by analyzing the development of the feeder line, the potential for increasing the number of passengers, and the infrastructure needs to support LRT operations in Palembang. The results show that four stations have the potential to develop feeder lanes, namely Asrama Haji station, RSUD station, Garuda Dempo station, and Polresta station, with the increased total number of potential passengers of 1460 passengers/day. The supporting infrastructure needed to support movement using LRT consists of a park and ride facilities, pedestrian bridges, the construction and repair of pedestrian facilities, and drop-off and pick-up facilities.
\end{abstract}

\section{Keywords}

LRT; Demand; Feeder system; Infrastructure needed

\section{Introduction}

Palembang City, as the Capital City of South Sumatera Province, attracted national attention due to in August 2018, it was the first city in Indonesia which operated Light Rail Transit (LRT). Having the construction of $23 \mathrm{~km}$ long and supported by 13 stations, the LRT operation is expected to decrease the congestion in Palembang City caused by the shift of users of other modes of transportation to LRT. As of March 2019, the existing feeders have not yet been sufficient to support the LRT operation, while the number of total passengers riding the LRT was still very small. For example, the number of passengers in February 2019 was 109.053 passengers/month. This shows that some efforts are needed to improve community connectivity to LRT stations. In increasing LRT services while at the same time increasing the number of passengers, the role of feeder development is very important, particularly from the nearest area to the LRT stations. This study aimed to analyze the potential for developing LRT feeders, estimate the added number of passengers, and analyze other supporting infrastructure needs.

\section{Literature Review}

Studies on mass transportation such as LRT and BRT, including the feeder system, have been widely reported $[1,2]$. Steijn [3] studied the demand for a new feeder system of Transjakarta and evaluated the different feeder systems and routes, especially for the demand of poor people in Greater Jakarta. Prayogi [4] studied the influence of BRT System on Urban Development with an Inquiry to Boston and Seoul BRT systems performance as the indicators. It was found that the two BRT systems of different performance could influence urban development around the system in various degrees. Zhu, H. [5] studied a feeder transport analysis for regional intermodal transport. This study provided an overview of feeder transport from a strategic and analytic perspective. Tabassum et al. [6] studied Feeder Network Design for Mass Transit System in Developing Countries and proposed the strategies for feeder design using the Gravity Model. Some studies concerning the feeder system were also reported by Phun, et al. [7], Purwanto and Manulang [8], Tangphaisankun, et al. [9] and Eria [10]. In this study, an analysis of the potential of the feeder line to support each station was carried out by taking into account the potential number of passengers based on population, availability of existing public transportation, condition, and capacity of the feeder lines.

\section{Methodology}

The research location was Palembang City having a 23 km LRT line with 13 stations, as shown in Figure 1. The research stages are shown in Figure 2 and explained as follows: 


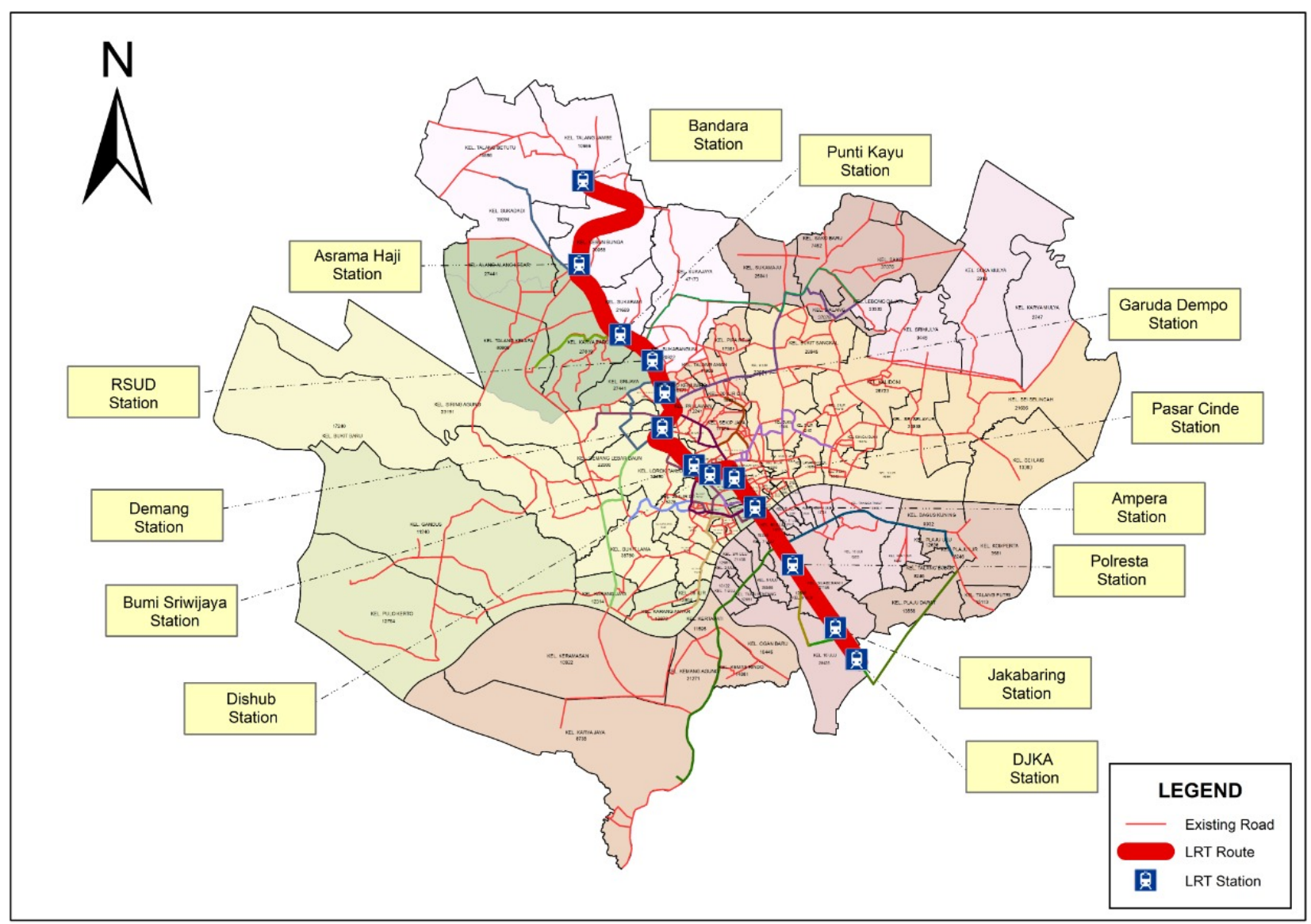

Figure 1 Location of study

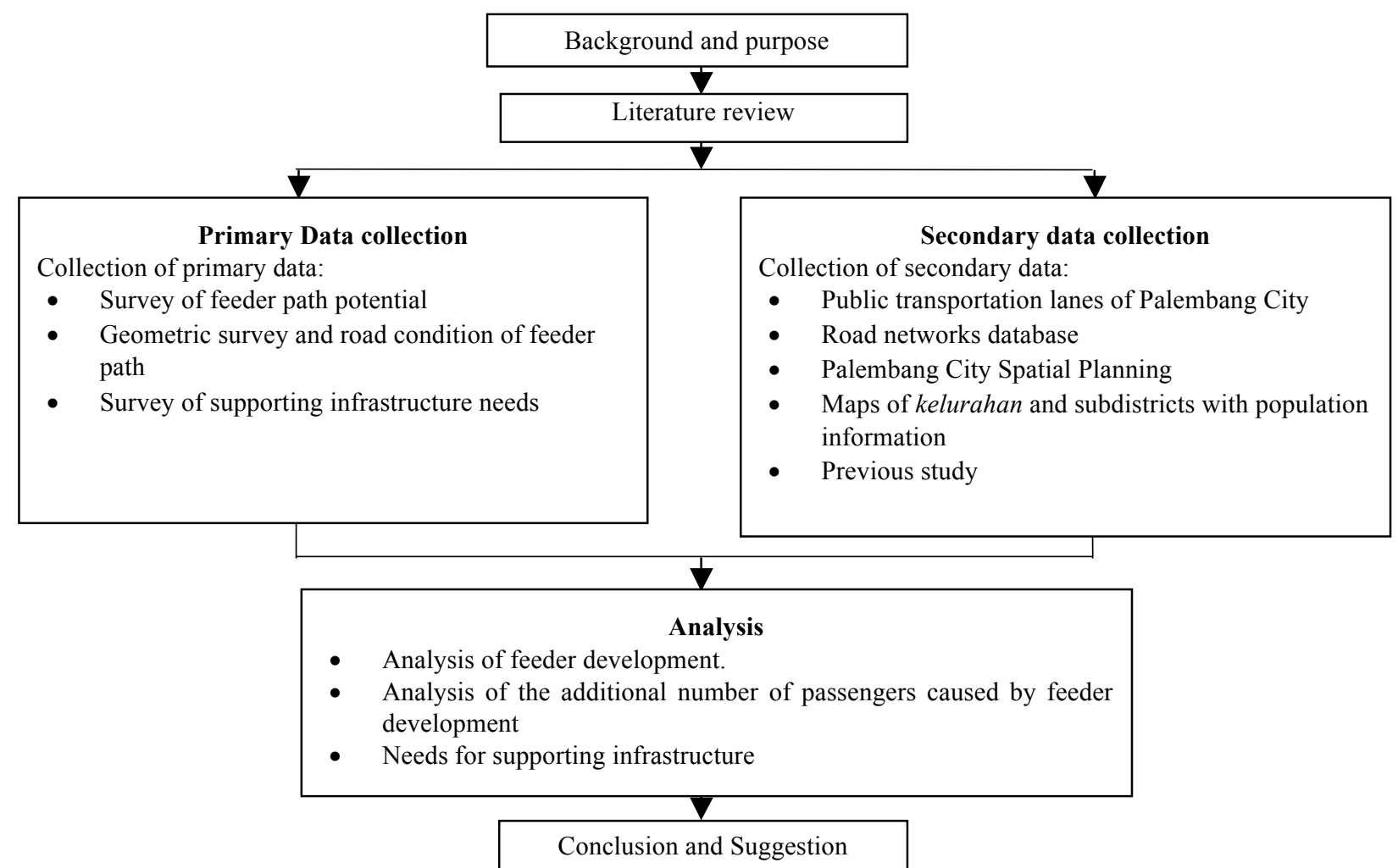

Figure 2 Research methodology 


\subsection{Data collection}

The data collection consisted of collecting primary data and secondary data. The survey of primary data collection is as follows:

1. The field survey of the potential feeder lines conducted after the decision of alternative feeder lines was based on population density and availability of road networks. The survey was conducted to evaluate the number of people to be served in the field, availability of networks, and alternative feeder connectivity with existing stations.

2. Geometric survey and road conditions on alternative feeders.

3. Survey of supporting infrastructure needs on the alternative feeder.

\subsection{Analysis}

The analysis was conducted as follows:

1. Analysis of the origin of travel destinations in Palembang City related to the services available on LRT.

2. Analysis of the determination of feeder lines, an additional number of passengers, and supporting infrastructure needs described below:

- Analysis of the determination of the feeder line was conducted to determine whether the alternative feeder could serve passengers to the maximum by considering how many passengers could be served and the connectivity of feeder lines and LRT stations.

- Feeder development was carried out in kelurahan with a population of more than 10,000 people.

- Geometric surveys and road conditions were conducted to find out the feasibility of geometric and road conditions on alternative feeder routes.

- Survey of supporting infrastructure needs was carried out to see the infrastructure needs of the feeder and other needed supporting infrastructure such as:

- Availability of land around the station for parking and riding facilities.

- Needs for pedestrian bridges.

- The facility needs to drop off and pick up.

- The needs for the development and improvement of pedestrian lane conditions.

\section{$4 \quad$ Findings and Discussion}

\subsection{Analysis of the number of LRT passengers}

The number of LRT passengers in February 2019 reached 109.053 passengers/month at which the Airport Station had the largest number of passengers of 561 passengers per day, and the Office of Transportation Station had the smallest number of passengers of 69 passengers daily. The existing number of passengers is very small for LRT operation. Figure 3 shows the overlap between the desire line of origin of destination and LRT lines of Palembang City.

Figure 3 shows that the origin of travel destinations in Palembang City is largely crossed from the LRT line [11], only a small portion of the destination originals are parallel to the LRT lane. The feeder system is needed to support the movement of prospective passengers, especially those from parallel travel destinations and towards the LRT lane.

\subsection{Analysis of feeder development}

Feeder development was conducted in order to get community movement connected directly to LRT stations. The stages of determining the feeder needs are explained as follows:

1. The needs for feeder mode were conducted by looking at the closest kelurahan to the LRT station, and it had potential demand (population > 10,000 people/kelurahan).

2. The alternative feeder is developed to a station of a potential kelurahan and not well connected to the existing public bus. Table 1 shows the connection between the 13 LRT stations and the existing public bus. There are four stations that are not fully integrated with the existing kelurahan, covering Stasiun Asrama Haji, Stasiun RSUD, Stasiun Garuda Dempo, and Stasiun Polresta.

The existing condition of Asrama Haji station is shown in Figure 4, where the catchment areas were served by this station are a portion of the villages that are in Subdistricts of Sukarami and Alang-Alang Lebar. Those areas have been connected by the Transmusi Bus of Alang-Alang Lebar route to the Airport and City Transportation route to Talang Betutu - Way Hitam. 


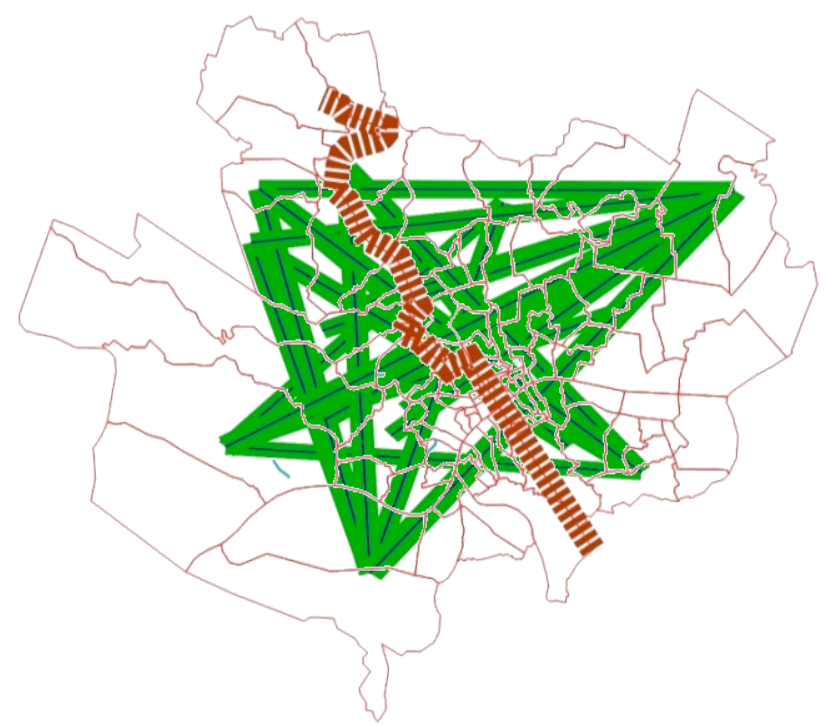

Figure 3 Lines of origin of travel destination in Palembang city

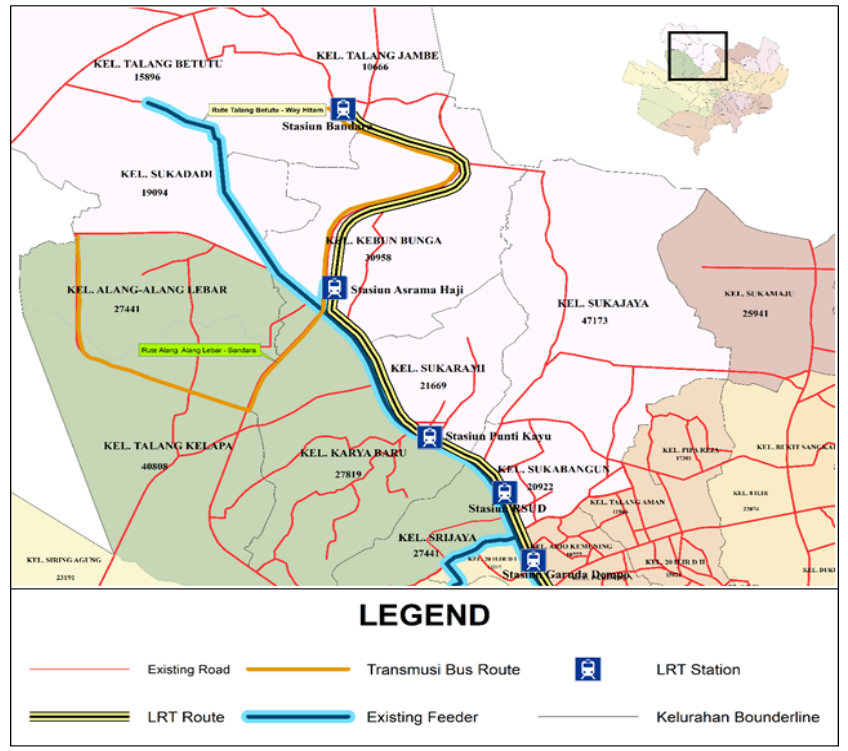

Figure 4 Existing condition of Asrama Haji station

Table 1 The connection between LRT Stations and Surrounding Areas

\begin{tabular}{|c|c|c|c|c|}
\hline No & Station & $\begin{array}{l}\text { Integrated by } \\
\text { existing feeder }\end{array}$ & Potential Subdistrict Served by Feeder & $\begin{array}{c}\text { Availability of road } \\
\text { network for a new } \\
\text { feeder lane }\end{array}$ \\
\hline 1 & Bandara & Yes & $\begin{array}{l}\text { Subdistrict that has potential demand and supply has been } \\
\text { connected by a feeder. }\end{array}$ & Unavailable \\
\hline 2 & Asrama Haji & Yes & $\begin{array}{l}\text { Kebun bunga ; Talang Kelapa ; Alang - Alang Lebar ; } \\
\text { Sukadadi }\end{array}$ & Available \\
\hline 3 & Punti Kayu & Yes & Sukarami ; Karyabaru ; Sukajaya & Unavailable \\
\hline 4 & RSUD & Yes & $\begin{array}{l}\text { Sukajaya ; Sukabangun ; Pipa Reja ; Talang Buruk ; Ario } \\
\text { Kemuning ; Srijaya }\end{array}$ & Available \\
\hline 5 & Garuda Dempo & Yes & Same as the RSUD Station & Available \\
\hline 6 & Demang & Yes & $\begin{array}{l}\text { Subdistrict that has potential demand and supply has been } \\
\text { connected by a feeder. }\end{array}$ & Unavailable \\
\hline 7 & Bumi Sriwijaya & Yes & $\begin{array}{l}\text { Subdistrict that has potential demand and supply has been } \\
\text { connected by a feeder. }\end{array}$ & Unavailable \\
\hline 8 & Dishub & Yes & $\begin{array}{l}\text { Subdistrict that has potential demand and supply has been } \\
\text { connected by a feeder. }\end{array}$ & Unavailable \\
\hline 9 & Cinde & Yes & $\begin{array}{l}\text { Subdistrict that has potential demand and supply has been } \\
\text { connected by a feeder. }\end{array}$ & Unavailable \\
\hline 10 & Ampera & Yes & $\begin{array}{l}\text { Subdistrict that has potential demand and supply has been } \\
\text { connected by a feeder. }\end{array}$ & Unavailable \\
\hline 11 & Polresta & Yes & 8 Ulu ; 5 Ulu ; 13 Ulu ; 3/4 Ulu ; 12 Ulu ; Silaberanti & Available \\
\hline 12 & Jakabaring & Yes & $\begin{array}{l}\text { Subdistrict that has potential demand and supply has been } \\
\text { connected by a feeder. }\end{array}$ & Unavailable \\
\hline 13 & DJKA & Yes & $\begin{array}{l}\text { Subdistrict that has potential demand and supply has been } \\
\text { connected by a feeder. }\end{array}$ & Unavailable \\
\hline
\end{tabular}

Figure 5 shows the potential for the feeder development of feeders that can be conducted in several kelurahan connected to Stasiun Asrama Haji covering Kelurahan Talang Kelapa with a population of 40,808 people, Kelurahan Alang-Alang Lebar with a population of 27,411 people and Kelurahan Kebun Bunga with a population of as many as 30,958 people. 


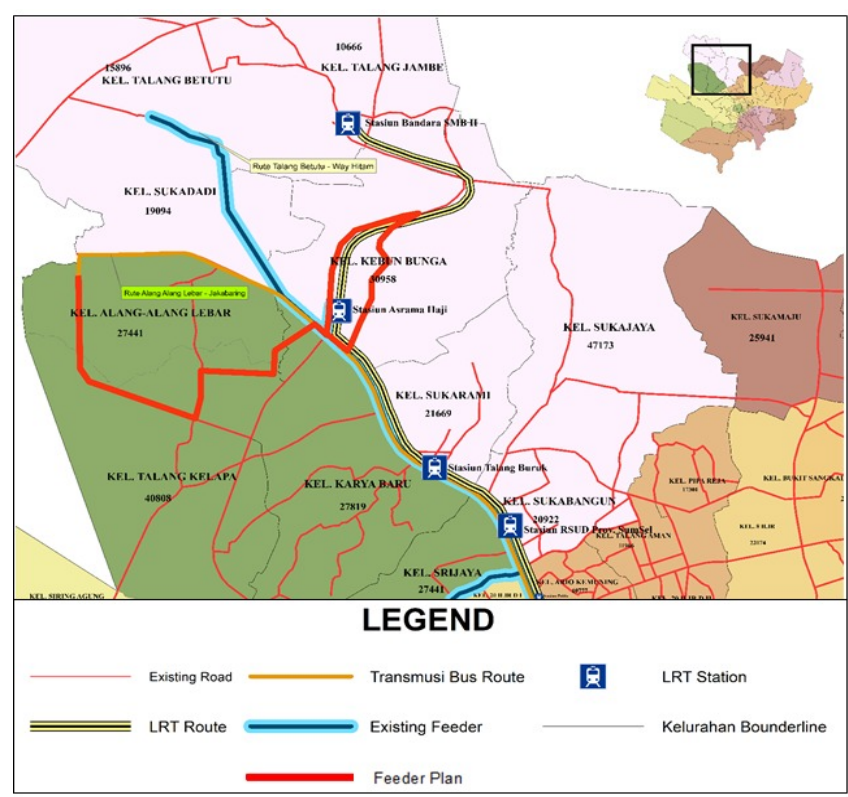

Figure 5 Feeder route development of Asrama Haji station

Figures 6 and 7 show the existing conditions and alternative feeders at RSUD Station and Garuda Dempo Station. Figures 8 and 9 show the existing conditions and alternative feeders at the Polresta Station and Jakabaring Station. Figure 10 shows stations that do not require the development of new feeders, namely at Stasiun Demang, Stasiun Bumi Sriwijaya, Stasiun Dishub, Stasiun Cinde, and Stasiun Ampera.

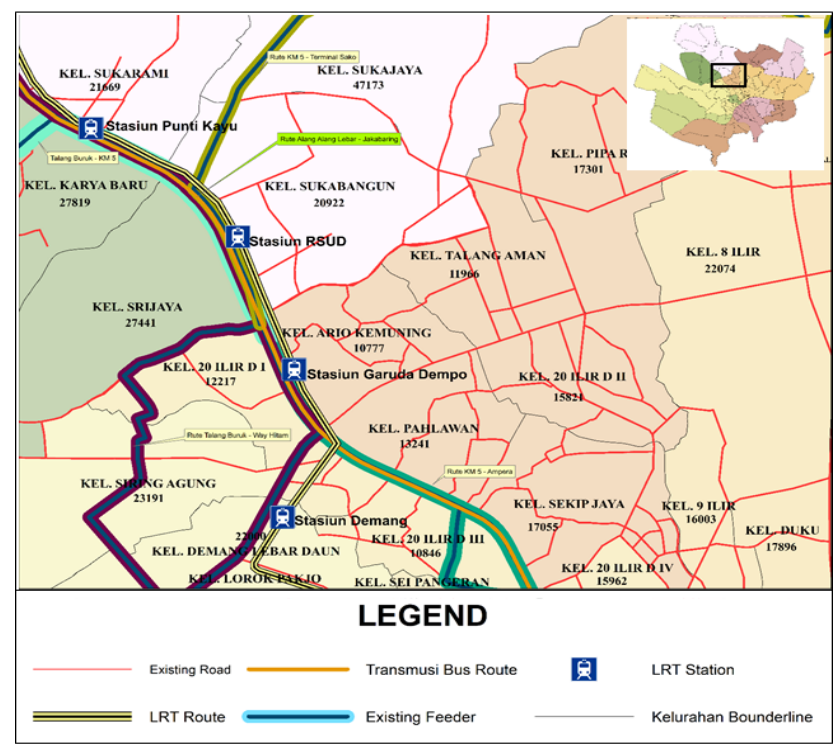

Figure 6 Existing conditions at RSUD station and Garuda Dempo station

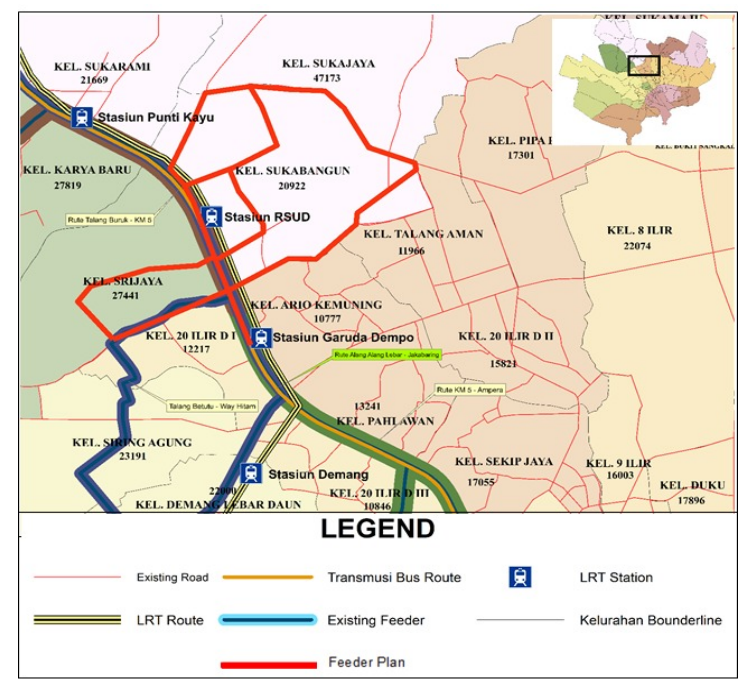

Figure 7 Alternative feeder route at RSUD station and Garuda Dempo station

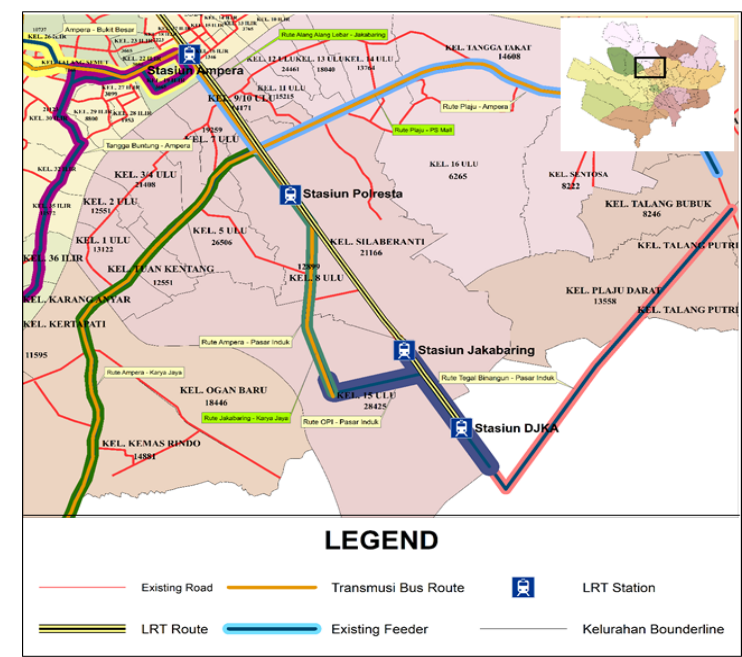

Figure 8 Existing condition at Polresta station and Jakabaring station

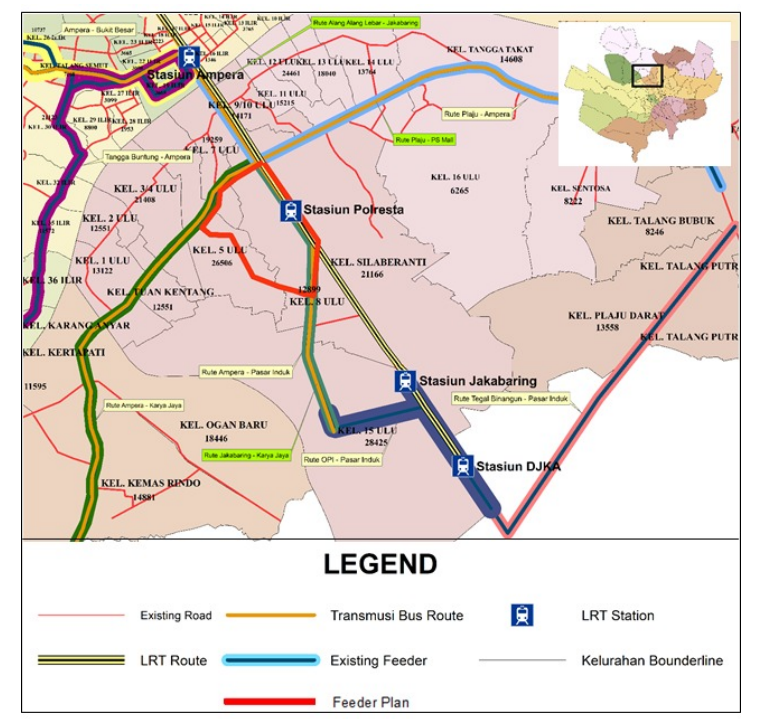

Figure 9 Alternative feeder route at Polresta station and Jakabaring station 


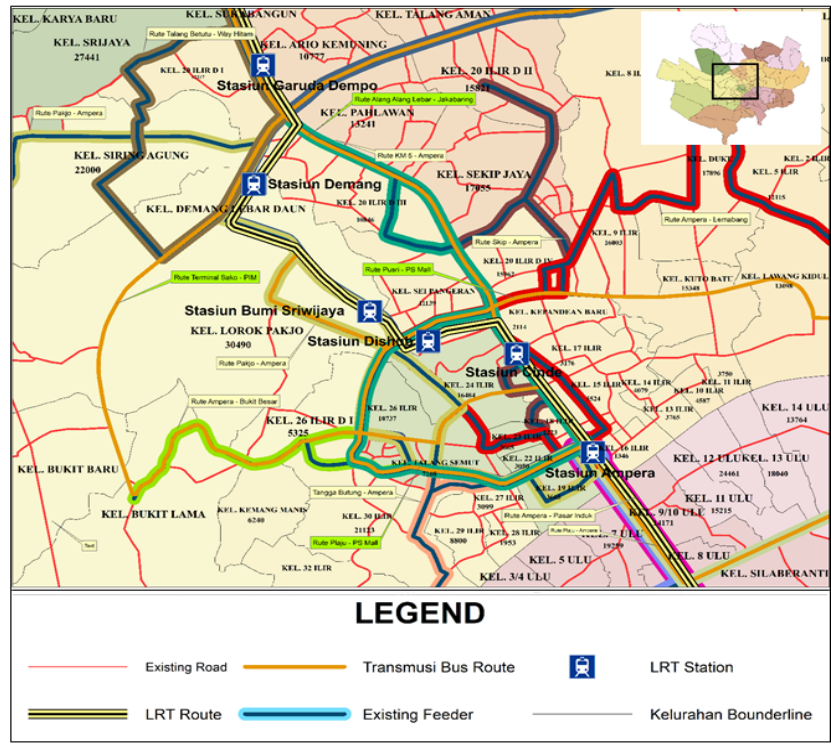

Figure 10 Feeder existing conditions surrounding Demang station, Bumi Sriwijaya station, Dishub station, Cinde station, and Ampera station

\subsection{Analysis of the potential of the number of passengers'}

The stages of getting the potential of the number of LRT passengers due to the feeder development are described as follows:

1. The matrix of the origin of the 2018 trip destination was developed from the previous study of Origin-Destination Matrix (MAT) [11].

2. The movement of origin of other modes of public transportation parallel to the LRT route was determined and potentially used the LRT, including the Transmusi bus mode and city transportation.

3. The analysis of the potential of each mode to move to the LRT mode is by finding out how much of the movement of public transport modes are connected to the LRT station and how much the users are willing to use LRT.

4. Of the developed feeder route, the passenger catchment area was calculated by finding out the route length and catchment width that were assumed to be 100 meters on the right side and 100 meters on the left side of the road.

5. Percentage of the catchment area toward the Subdistrict area was calculated using the following formula:

$$
\begin{gathered}
\text { Area of } \\
\frac{\text { Feeder route catchment }}{\text { Area of the subdistrict }} \\
\text { passed by }
\end{gathered}
$$

6. Calculating the potential of users that shifted from an existing mode to ride LRT at Asrama Haji station, the following assumption is used:

$$
\mathrm{P}=\% \mathrm{LT} \times \mathrm{PM} \times \mathrm{WTU}
$$

where,

$$
\begin{aligned}
\mathrm{P} & =\begin{array}{l}
\text { Potential of LRT Passenger shifting } \\
\text { from a Transportation Mode }
\end{array} \\
\% \mathrm{LT}= & \text { Area of feeder lane catchment } \\
\text { The number of users of public } & \begin{array}{l}
\text { transportation mode at a subdistrict } \\
\text { passed by a feeder derived from the } \\
\text { matrix of the destination origin }
\end{array} \\
& \begin{array}{l}
\text { Willingness to use LRT mode from } \\
\text { public transportation mode being } \\
\text { reviewed. }
\end{array}
\end{aligned}
$$

Willingness to Use factor of each mode is obtained from the previous study and shown in Table 2 [12].

Table 2 Willingness to Use from Existing Mode to LRT for the tariff of Rp.5000, -.

\begin{tabular}{cccc}
\hline No & Mode & \multicolumn{2}{c}{ Percentage of WTU } \\
\hline 1 & City Transportation & $14,8 \%$ & 0,148 \\
2 & Being Picked up & $7,5 \%$ & 0,075 \\
3 & City Bus/Transmusi & $4,0 \%$ & 0,040 \\
4 & Bicycles & $0,3 \%$ & 0,003 \\
\hline \multicolumn{4}{c}{ Source: Sarwandy et al. 2018 2012$]$}
\end{tabular}

By using the steps outlined above, the total potential demand of LRT users after the feeder development is shown in Table 3. It was found that the total additional passengers with the potential to ride LRT were 2249 passengers/day.

Table 3 Total Potential Demand of LRT Users

\begin{tabular}{ccc}
\hline No & Station & $\begin{array}{c}\text { LRT Passengers } \\
\text { (Trip/day) }\end{array}$ \\
\hline 1 & Asrama Haji & 335 \\
2 & RSUD & 416 \\
3 & Garuda Dempo & 247 \\
4 & Polresta & 443 \\
\hline & Total & 1460 \\
\hline
\end{tabular}

\subsection{Analysis of supporting infrastructure needs}

The analysis of supporting infrastructure needs is as follows: Analysis of land availability for parking and riding nearby the station for: 
- Bicycles, motorbikes, and cars if the land is sufficient.

- Only for bicycles and motorbikes if the land is unavailable or limited.

1. Needs for pedestrian bridges considers the existing condition of the station:

- It is needed if the stairs or escalators of the station are available on one side of the street.

- It is not needed if the stairs or escalators are available on both sides of the street.

2. Needs for improvement and repair of pedestrian lines.

3. Availability of facility of Drop off and pick up.

Table 4 shows a summary of the supporting infrastructure needs at LRT stations. It indicates that:
1. The passengers shifting from personal cars, motorbikes, and bicycles to LRT mode was still not optimal since there is no facility for parking and riding. The empty land for parking and riding is still available, but most of them belong to the people.

2. In order to make people easy to go to a station, some stations need pedestrian bridges.

3. LRT stations still require the facilities for Drop off and pick up except for Dishub station and Bandara station.

4. It still needs repair of the facility for pedestrians to improve access for them.

Table 4 Supporting Infrastructure Needs at LRT Stations

\begin{tabular}{|c|c|c|c|c|c|c|c|}
\hline \multirow[t]{2}{*}{ No. } & \multirow[t]{2}{*}{ Station } & \multirow{2}{*}{$\begin{array}{c}\text { Availability of Park and } \\
\text { Ride }\end{array}$} & \multirow{2}{*}{$\begin{array}{c}\text { Pedestrian } \\
\text { Bridge Needs }\end{array}$} & \multirow{2}{*}{$\begin{array}{l}\text { Drop off and } \\
\text { Pick up Needs }\end{array}$} & \multirow{2}{*}{$\begin{array}{l}\text { Pedestrian } \\
\text { Route }\end{array}$} & \multicolumn{2}{|c|}{$\begin{array}{c}\text { Stairs and Elevator } \\
\text { Availability }\end{array}$} \\
\hline & & & & & & Right side & Left side \\
\hline 1. & DJKA & $\begin{array}{c}\text { Available } \\
\text { (car, motorbike, bicycle) }\end{array}$ & Unnecessary & Necessary & Available & Stairs & Elevator \\
\hline 2. & Jakabaring & $\begin{array}{c}\text { Available } \\
\text { (car, motorbike, bicycle) }\end{array}$ & Unnecessary & Necessary & Available & Elevator & Elevator \\
\hline 3. & Polresta & $\begin{array}{c}\text { Available } \\
\text { (car, motorbike, bicycle) }\end{array}$ & Necessary & Necessary & Available & Elevator & Unavailable \\
\hline 4. & Ampera & $\begin{array}{c}\text { Available } \\
\text { (car, motorbike, bicycle) }\end{array}$ & Unnecessary & Necessary & Available & Elevator & Unavailable \\
\hline 5. & Cinde & $\begin{array}{c}\text { Available } \\
\text { (car, motorbike, bicycle) }\end{array}$ & Unnecessary & Necessary & Available & Elevator & Stairs \\
\hline 6. & Dishub & Unavailable & Necessary & Necessary & Available & Unavailable & Escalator \\
\hline 7. & Bumi Sriwijaya & $\begin{array}{c}\text { Available } \\
\text { (car, motorbike, bicycle) }\end{array}$ & Unnecessary & Necessary & Available & Elevator & Elevator \\
\hline 8. & Demang & $\begin{array}{c}\text { Available } \\
\text { (motorbike, bicycle) }\end{array}$ & Necessary & Necessary & Available & Unavailable & Elevator \\
\hline 9. & Garuda Dempo & $\begin{array}{c}\text { Available } \\
\text { (car, motorbike, bicycle) }\end{array}$ & Necessary & Necessary & Available & Elevator & Unavailable \\
\hline 10. & RSUD & $\begin{array}{c}\text { Available } \\
\text { (car, motorbike, bicycle) }\end{array}$ & Unnecessary & Necessary & Available & Elevator & Stairs \\
\hline 11. & Punti Kayu & $\begin{array}{c}\text { Available } \\
\text { (car, motorbike, bicycle) }\end{array}$ & Necessary & Necessary & Available & Unavailable & Stairs \\
\hline 12. & Asrama Haji & $\begin{array}{c}\text { Available } \\
\text { (car, motorbike, bicycle) }\end{array}$ & Necessary & Necessary & Available & Unavailable & Stairs \\
\hline 13. & Bandara & $\begin{array}{c}\text { Available, } \\
\text { (Unnecessary) }\end{array}$ & Unnecessary & Unnecessary & Available & Unavailable & Elevator \\
\hline
\end{tabular}




\section{Conclusion}

This study concludes that:

1. The analysis of feeder needs shows that there are four stations to be potential to develop LRT operational supporting feeder lanes in Palembang, namely Stasiun Asrama Haji, Stasiun RSUD, Stasiun Garuda Dempo, and Stasiun Polresta.

2. The development of feeders at the four stations above has the potential to increase the number of LRT passengers by 1460 passengers/day.

3. The needs of infrastructure to support the operation of LRT stations in the form of parking and riding facilities for cars, motorbikes, and bicycles; pedestrian bridges; construction and improvement of facility conditions for pedestrian and drop-off and pick-up.

\section{Acknowledgment}

This work was supported by USAID through the Sustainable Higher Education Research Alliances (SHERA) program under grant number IIE00000078ITB-1., and the author would like to express his gratitude for the opportunity of getting the USAID grant.

\section{References}

[1] K. N. S. Ayuningtyas, R. B. Frazila, S. S. Wibowo, W. Weningtyas, and M. Farda, "Network Analysis of Intercity Bus Terminal and Inner-City Toll Road Development-The Case of Bandung City" Int. J. Sustain. Transp. Technol., vol. 2, no. 1, pp. 8-18, Apr. 2019.

[2] M. Farda and H. Lubis, "Transportation System Development and Challenge in Jakarta Metropolitan Area,
Indonesia," Int. J. Sustain. Transp. Technol., vol. 1, no. 2, pp. 42-50, Oct. 2018.

[3] J. Steijn, "Creating feeder bus lines for Transjakarta BRT: Understanding spatial patterns of daily destinations from poverty origin zones in Jakarta to determine demand for a new feeder system of Transjakarta BRT," BS thesis. University of Twente, 2014.

[4] L. Prayogi, "The influence of bus rapid transit system on urban development: An inquiry to Boston and Seoul BRT systems' performance indicators," Int. J. Built Env. Scient. Res., vol. 1, no. 1, pp. 1-8, 2017.

[5] H. Zhu, "Feeder transport analysis for regional international transport, Case study: Malaren Region," KTH Architecture and the Built Environment. Master of science Thesis Stockholm, 2012.

[6] S. Tabassum, S. Tanaka, F. Nakamura and A. Ryo, "Feeder network design for mass transit system in developing countries (case study of Lahore, Pakistan)," Transp. Res. Proc., vol. 25, pp. 3129-3146, 2017.

[7] V. K. Phun, and T. Yai, "Intention of paratransit drivers to operate as feeder service of public bus in Phnom Penh," Transp. Pol. Stud. Rev., vol. 19, no. 2, pp. 2-014, 2016.

[8] E. Purwanto and O. R. Manullang. "Evaluation of sidewalk as a non-motorized feeder to support bus rapid transit (BRT) In Semarang City," Jurn. Pemb. Wil. Kot., vol. 14, no. 1 , pp. 17-27, 2018 .

[9] A. Tangphaisankun, F. Nakamura and T. Okamura, "Influences of paratransit as a feeder of mass transit system in developing countries based on commuter satisfaction," Proceedings of the Eastern Asia Society for Transportation Studies (The 8th International Conference of Eastern Asia Society for Transportation Studies) vol. 7, pp. 236-236, 2009.

[10] Eria, "Design and analysis of feeder-line bus', in Kutani, I. and Y. Sado (eds.), addressing energy efficiency in the transport sector through traffic improvement," ERIA Research Project Report 2015-10, pp. 60-76, 2016.

[11] J. Arliansyah, "Study of river transport development in Palembang City," National Strategic Research Grant, 2016.

[12] M. H. A. Sarwandy, J. Arliansyah and H. Fitriani, "The Analysis of ability to pay (ATP) and willingness to pay (WTP) on light rail transit (LRT) Tariff in Palembang," Journal of Physics: Conference Series, IOP Publishing, vol. 1198, no. 8, pp. 082023, 2019. 